\title{
Çevre Muhasebesi ve Çevresel Politikalara Verilen Önem Düzeyi: Erzurum-Erzincan Karşılaştırması*
}

\begin{abstract}
Alirıza $\breve{A G}^{* *}$
Öz

Doğadaki çevresel kaynakların kullanımı sonucu ortaya çıkan etkilerin muhasebeleştirilmesi olarak ifade edilen çevre muhasebesinin bir diğer ifade ile doğal kaynaklar muhasebesinin temelinde sosyal sorumluluk kavramı yatmaktadır. $\mathrm{Bu}$ doğrultuda çalışmamızın amacı Erzurum ve Erzincan illerinde faaliyet gösteren üretim işletmelerinin sosyal sorumluluk kavramı çerçevesinde çevre muhasebesine ve çevresel politikalara verdikleri önem düzeyinin tespit edilmesidir. Araştırmada faktör analizi yöntemi kullanılarak oluşturulan model çerçevesinde işletmelere ait özellikler ile çevre muhasebesi uygulamaları ve çevresel politikalar karşılaştırılmıştır. Yapılan analizlerde işletmelerin faaliyet süreleri ve faaliyette bulundukları iller ile çevre muhasebesi ve çevresel politikalar arasında anlamlı ilişkiler tespit edilmiş olup özellikle Erzurum ilinde faaliyet gösteren kurumsal nitelikteki işletmelerin çevresel politikalara daha fazla önem verdiği tespit edilmiştir.
\end{abstract}

Anahtar Kelimeler: Çevre, Muhasebe, Çevre Muhasebesi, Çevresel Politikalar, Çevresel Uygulamalar

\section{Environmental Accountancy and Importance Level of Environmental Policies: A Comparison between Erzurum and Erzincan}

Sayfa/Page | 89

IGU J. Soc. Sci., 4 (2), Spec. Iss. of ICEFM 2017, pp. 89-105.

\footnotetext{
Abstract

In other words, environmental accounting, which is expressed as accounting for the resulting effects of the use of natural resources in the environment, is based on the concept of social responsibility at the basis of natural resources accounting. The aim of our work in this direction is to determine the level of importance given to environmental accounting and environmental policy by the production enterprises operating in Erzurum and Erzincan provinces within the framework of social responsibility concept. In this study, the characteristics of the enterprises in the

Özgün Araştırma Makalesi (Original Research Article)

Geliş Tarihi: 22.08.2017 Kabul Tarihi: 26.12.2017

DOI: http://dx.doi.org/10.17336/igusbd.388037

* Bu çalıșma, Atatürk Üniversitesi Sosyal Bilimler Enstitüsü’nün belirlediği jüri tarafından 13.07.2016 tarihinde kabul edilen "Sosyal Sorumluluk Anlayışı Çerçevesinde Üretim İşletmelerinin Çevre Muhasebesine Verdikleri Önem: TRA1 Bölgesinde Bir Araştırma" isimli doktora tezinden türetilmiştir ${ }^{* *}$ Yrd. Doç. Dr., Bayburt Üniveristesi, İktisadi ve İdari Bilimler Fakültesi, Bayburt, Türkiye, E-posta: alirizaag@bayburt.edu.tr ORCID ID https://orcid.org/0000-0001$\underline{5345-6245}$
} 
Sayfa/Page | 90

İGÜ Sos. Bil. Derg., 4 (2), ICEFM 2017 Özel Sayısı ss. $89-105$ framework of the model created by using the factor analysis method and the environmental accounting practices and the environmental policies were compared. In analyzes that have been made, it was determined that there is a significant relationship between the activity periods of the enterprises and the activities they are engaged in, environmental accounting and environmental policies, in particular, it has been determined that institutional enterprises operating in the Erzurum province attach more importance to environmental policy.

Keywords: Environment, Accounting, Environmental Accounting, Environmental Policies, Environmental Applications

\section{Giriş}

Sanayi devrimi ile birlikte teknolojide meydana gelen değişim ve gelişmeler sonucunda insanların doğaya müdahaleleri artmıştır. Bunun sonucunda doğanın dengesi bozulmaya bașlamakla beraber gerek insanoğlunun gerekse yeryüzündeki diğer canlıların yaşamları tehlikeye girmiștir. ${ }^{1}$

Dünya nüfusunun her geçen gün giderek artması, insanların sınırsız ihtiyaçları ile insanlardaki aşırı tüketim olgusunun giderek artması sebebiyle işletmelerin sayısı her geçen gün artmaktadır. Bu artışlara karşılık doğadaki kıt olan kaynaklar giderek azalmaktadır². Toplumun ihtiyaçlarını karşılamak ve kâr elde etmek amacıyla ekonomik değeri olan mal ve hizmet üretip pazarlamak amacıyla kurulan işletmeler faaliyetlerini sürdürürken doğal kaynakları kullanmaktadırlar. Dolayısıyla işletmelerin üretim faaliyetleri sonucunda gaz emisyonları, toksik ve katı atıklar gibi doğaya zararlı unsurlar ortaya çıkmaktadır. Ortaya çıkan bu zararlı unsurlar çevre kirliliğine sebep olmaktadır ${ }^{3}$. Şunu söyleyebiliriz ki çevresel sorunlar işletmelerin ekonomik faaliyetlerinden değil, doğadaki kıt kaynakların rasyonel olarak kullanılmamasından ortaya çıkabilmektedir.

1970'li yıllarda çevresel sorunların giderek artması ve çevresel sorunların çözümüne yönelik arayışların yoğunlaşması ile birlikte çevre muhasebesi, çevresel maliyetlerin hesaplanması konuları gün yüzüne çıkmıștır. $\mathrm{Bu}$ bağlamda özellikle Uluslararası Standartlar Örgütünün hazırladığı ISO 14000 Çevre Yönetim Standartları muhasebe sistemi içerisinde yeni yaklaşımların geliştirilmesine zemin hazırlamış olup, çevre muhasebesi

${ }^{1}$ Umut Tuğlu, Çevre Muhasebesi ve Alanya'daki Bir Konaklama İșletmesindeki Uygulanması, Yayımlanmamış Yüksek Lisans Tezi, Antalya, Akdeniz Üniversitesi Sosyal Bilimler Enstitüsü, 2010, s. 4.

2 Ela Hiçyorulmaz, Çevre Muhasebesi ve Çimento Fabrikalarının Çevre Muhasebesine Olan Duyarlılı̆ıl: Çorum Votorantim Çimento Fabrikası Uygulaması, Yayımlanmamış Yüksek Lisans Tezi, Çorum, Hitit Üniversitesi Sosyal Bilimler Enstitüsü, 2015, s. 4. ${ }^{3}$ Muhsin Celik, "CCevreye Duyarlı Muhasebe", Muhasebe Finansman Dergisi, Sayı 33, Ocak, 2007, s. 151-161. 
kavramının ortaya çıkmasına neden olmuştur. ${ }^{4}$ Yeşil muhasebe olarak da adlandırılan çevre muhasebesi çevresel kaynakların oluşumunu, kullanım biçimini, işletmelerin gerçekleştirdikleri faaliyetler sonucunda bu kaynaklarda meydana gelen artış ve azalışları ve işletmelerin çevresel faaliyetlerini açıklayan bilgileri üreten ve bu bilgileri ilgili kişi ve kurumlara ileten bir bilgi sistemidir. Bir başka ifade ile çevre muhasebesi finansal nitelikteki çevresel işlemlerin ve olayların parasal olarak ifade edilerek kaydedilmesi, sınıflandırılması, özetlenmesi ve raporlanması sürecidir. ${ }^{5} \mathrm{Bu}$ doğrultudan hareketle çalışmanın temel amacı Erzurum ve Erzincan illerinde faaliyet gösteren üretim işletmelerinin çevre muhasebesine ve çevresel politikalara verdikleri önem düzeyinin belirlenmesidir.

\section{2. Çevre Muhasebesi ve Amaçları}

Çevresel sorunların giderek artması, doğadaki kıt kaynakların aşırı tüketilmesi sonucunda özellikle 1970'li yıllardan itibaren çevresel konuların muhasebe sistemi içerisinde gösterilmesi ihtiyacını doğurmuştur 6

Literatürde yeșil muhasebe olarak da adlandırılan çevre muhasebesinin değişik tanımları yapılmıştır. Çevre muhasebesi; "uygulanmakta olan muhasebe sistemlerinde özellikle de maliyet ve kar analizlerinde çevresel faktörlerin planlanması ve uygulanmasıdır"7. Japon Çevre Bakanı ise çevre muhasebesini; "çevre koruma faaliyetlerinde harcamaların ve faydaların niceliksel olarak değerlendirilmesi" şeklinde ifade etmiştir. 8 Çevre muhasebesi; "finansal muhasebede ölçümleme işlevlerinde çevresel etmenlerin göz önünde bulundurulması, finansal ve finansal olmayan muhasebe sistemlerinin iyileştirilmesidir" 9

En genel anlamıla çevre muhasebesi; çevresel kaynakların oluşumunu, kullanım biçimini, işletmelerin gerçekleştirdikleri faaliyetler sonucunda bu kaynaklarda meydana gelen artış ve azalışları ve işletmelerin çevresel faaliyetlerini açılayan bilgileri üreten ve bu bilgileri ilgili kişi ve kurumlara ileten bir bilgi sistemi olarak ifade edilebilir.

\footnotetext{
${ }^{4}$ Yıldırım Ercan Çalıș, "Çevresel Maliyetlerin Muhasebeleștirilmesi", Marmara Üniversitesi I.I.I.B.Dergisi, Cilt XXXIV, Sayı 1, 2013, s. 175-190.

${ }^{5}$ Hilmi Kırlıoğlu ve Ahmet Vecdi Can, Çevre Muhasebesi, Sakarya, Değişim Yayınları, 1998, s. 56

${ }^{6}$ Füsun Özay Baltacı, Çevre Maliyetleri ve Bir Sanayi I̦șletmesinde Uygulama Yayımlanmamış Yüksek Lisans Tezi, Kocaeli, Kocaeli Üniversitesi Sosyal Bilimler Enstitüsü, 2009, s.30

7 Oktay Güvemli ve Ümit Gökdeniz, "Çevre Muhasebesindeki Gelişmeler", Muhasebe Bilim Dünyası Dergisi, Cilt 1, Sayı 4, 1996, s. 24-28.

${ }^{8} \mathrm{Tu}$, Jui-Che and Hsieh-Shan Huang, "Analysis on the relationship between green accounting and green design for enterprises." Sustainability Volume 7, Number 5, 2015, s. 6264-6277.

${ }^{9}$ Gray, R., Bebbington, J. Walters, D, Accounting for the Environment, Founded by the Chartered Association of Certified Accountants, London: Paul Chapman, 1993, s. 7.
}

Sayfa/Page | 91

IGU J. Soc. Sci., 4 (2), Spec. Iss. of ICEFM 2017, pp. 89-105. 
Sayfa/Page | 92

İGÜ Sos. Bil. Derg., 4 (2), ICEFM 2017 Özel Sayısı, ss. $89-105$

Çevre muhasebesinin temel amacı işletmelerin sosyal sorumlulukları gereği çevreye vermiş oldukları zararların topluma bildirilmesine yardımcı olmaktır. Bunun yanı sıra bilgi üretmek, kaynakların envanterini çıkarmak, mamul maliyetlerinin doğru hesaplanmasını sağlamak ve işletmelerin çevresel performanslarını değerlendirmelerine yardımcı olmak çevre muhasebesinin amaçları arasında gösterilebilir ${ }^{10}$. Çevre muhasebesinin makro ekonomik açıdan amacı kullanılan çevresel kaynakların değerini parasal olarak ifade ederek onların milli gelir hesaplarında gösterilmesini sağlamak, böylece çevresel veriler ile ekonomik verileri aynı çatı altında toplamaktır. Mikro ekonomik açıdan amacı ise çevre ile ilgili konulara mali nitelik kazandırılması ve böylece çevresel faaliyetlerin finansal tablolarda gösterilerek çevrenin muhasebe sistemi içine dahil edilmesidir. ${ }^{11}$

\section{3. Çevre Muhasebesi ve Çevresel Politikalara Verilen Önem Düzeyi: Erzurum-Erzincan Karşılaştırması}

Çalışmanın bu bölümünde Erzurum ve Erzincan Bölgesinde faaliyet gösteren üretim işletmelerinin "Çevre Muhasebesine ve Çevresel Politikalara " verdikleri önem düzeyinin belirlenmesi amaçlanmıştır. $\mathrm{Bu}$ doğrultuda verilerin elde edilmesinde anket yöntemi kullanılmış olup sonuçların değerlendirilmesinde faktör analizi kullanılmıştır. Daha sonraki aşamada ise bu bölgede faaliyet gösteren üretim işletmelerinin çevre muhasebesine verdikleri önem düzeyi belirlenerek, çevresel sorunları önlemeye yönelik çevresel politikaları tespit edilmiştir.

\subsection{Araştırmanın Amacı ve Önemi}

Araştırmanın amacı Erzurum ve Erzincan illerinde faaliyet gösteren üretim işletmelerinin çevre muhasebesine ve çevresel politikalara verdikleri önem düzeyinin belirlenmesidir. Böylelikle bölgede faaliyet gösteren üretim işletmelerinin çevre muhasebesine ve çevresel politikalara verdikleri önem düzeyi belirlenecek olup, araştırma sonucunda elde edilen verilerle diğer bölgelerin kıyaslanmasına olanak sağlamakla birlikte daha sonra yapılacak çalışmalara alt yapı olușturması hedeflenmektedir.

\subsection{Araştırmanın Anakütle ve Örneklemi}

Araştırmanın ana kütlesini Erzurum ve Erzincan illerinde faaliyet gösteren üretim işletmeleri oluşturmaktadır. Bu doğrultuda 129 üretim işletmesine anket uygulanmıştır.

\subsection{Araştırmanın Veri Toplama ve Analiz Yöntemi}

$\mathrm{Bu}$ araștırmada verilerin toplanmasında anket yöntemi kullanılmıştır. Araştırmada İç tutarlılığın ve yapı geçerliliğinin saptanmasında Cronbach $\alpha$

${ }^{10}$ Füsun Özay Baltacı, a. g. T., s. 31

${ }^{11}$ Hilmi Kırlıoğlu ve Ahmet Vecdi Can, a. g. e., s. 56 
kat sayısı ve temel bileşenler analizi (faktör analizi) kullanılmış olup önemlilik düzeyi olarak $\mathrm{p}<0.05$ anlamlı sayılmıştır.

\subsection{Araştırmanın Modeli ve Hipotezleri}

Araştırmada kullanılan faktör analizi yöntemi sonucunda faktör yükleri tespit edilmiş olup, elde edilen faktör yükleri doğrultusunda aşağıdaki model oluşturulmuștur.

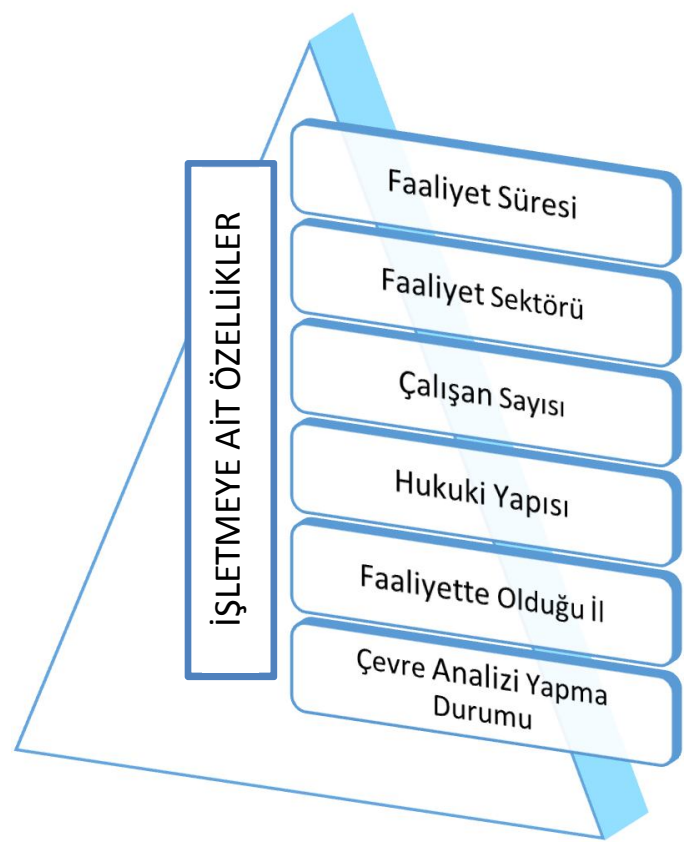

Sayfa/Page | 93

IGU J. Soc. Sci., 4 (2), Spec. Iss. of ICEFM 2017, pp. 89-105.

\section{Şekil 1: Araştırma Modeli}

\section{$\mathrm{H}_{1}$ : İşletmeye ait özellikler "çevre muhasebesi uygulamaları" boyutunu etkilemektedir.}

$\mathrm{H}_{1 \mathrm{a}}$ : İşletmelerin faaliyet süreleri çevre muhasebesi uygulamaları boyutunu etkilemektedir.

$\mathrm{H}_{1 \mathrm{~b}}$ : İşletmelerin faaliyette bulundukları sektörler çevre muhasebesi uygulamaları boyutunu etkilemektedir.

$\mathrm{H}_{1 c}$ : İşletmelerin çalışan sayıları çevre muhasebesi uygulamaları boyutunu etkilemektedir.

$\mathrm{H}_{1 \mathrm{~d}}$ : İşletmelerin hukuki yapıları çevre muhasebesi uygulamaları boyutunu etkilemektedir.

$\mathrm{H}_{1 \mathrm{e}}$ : İşletmelerin faaliyette bulundukları iller çevre muhasebesi uygulamaları boyutunu etkilemektedir.

$\mathrm{H}_{1 \mathrm{f}}$ : İşletmelerin çevre analizi yapma durumları çevre muhasebesi uygulamaları boyutunu etkilemektedir. 
Sayfa/Page | 94

İGÜ Sos. Bil. Derg., 4 (2), ICEFM 2017 Özel Sayısı ss. $89-105$

\section{etkilemektedir.}

$\mathrm{H}_{2 \mathrm{a}}$ : İşletmelerin faaliyet süreleri çevresel politikalar boyutunu etkilemektedir.

$\mathrm{H}_{2 b}$ : İşletmelerin faaliyette bulundukları sektörler çevresel politikalar boyutunu etkilemektedir.

$\mathrm{H}_{2 c}$ : İşletmelerin çalışan sayıları çevresel politikalar boyutunu etkilemektedir.

$\mathrm{H}_{2 \mathrm{~d}}$ : İşletmelerin hukuki yapıları çevresel politikalar boyutunu etkilemektedir.

$\mathrm{H}_{2 \mathrm{e}}$ : İşletmelerin faaliyette bulundukları iller çevresel politikalar boyutunu etkilemektedir.

$\mathrm{H}_{2 \mathrm{f}}$ : İşletmelerin çevre analizi yapma durumları çevresel politikalar boyutunu etkilemektedir.

\subsection{Bulgular}

Çalışmanın bu kısmında Erzurum ve Erzincan İllerinde faaliyet gösteren üretim işletmelerine uygulanan anketlerden elde edilen bulgulara yer verilecektir.

\subsubsection{Araștırmaya Katılan İșletmeler Hakkında Genel Bilgiler}

Araştırma kapsamına Erzurum ve Erzincan İllerinde faaliyet gösteren toplam 129 üretim işletmesi dâhil edilmiştir. Bu işletmelerin \% 62,01'i Erzurum, \%37.99'u Erzincan'da faaliyet göstermektedir. İller bazında üretim işletmelerinin dağılımı ve yüzdesi Tablo 1'de verilmiştir.

Tablo 1. İşletmelerin İllere Göre Dağılımları

\begin{tabular}{|l|l|l|}
\hline İller & N & \% \\
\hline Erzurum & 80 & 62,01 \\
\hline Erzincan & 49 & 37,99 \\
\hline Tüm Örneklem & 129 & 100 \\
\hline
\end{tabular}

Araştırmaya katılan işletmelerin hukuki yapılarına göre dağılımı Tablo 2 ' verilmiştir. Tablo 2'de görüldüğü gibi işletmelerin büyük bir bölümü limited şirket statüsündedir. 
Tablo 2. İllere Göre İşletmelerin Hukuki Yapıları

\begin{tabular}{|l|l|c|c|}
\hline \multicolumn{2}{|c|}{ İşletmenin Faaliyette Bulunduğu İl } & N & \% \\
\hline \multirow{4}{*}{ Erzurum } & Adi Şirket & 2 & 2,5 \\
\cline { 2 - 4 } & Kollektif Şirket & 1 & 1,3 \\
\cline { 2 - 4 } & Anonim Şirket & 25 & 31,3 \\
\cline { 2 - 4 } & Limited Şirket & 52 & 65,0 \\
\cline { 2 - 4 } & Toplam & 80 & 100 \\
\hline \multirow{4}{*}{ Erzincan } & Adi Şirket & 1 & 2,0 \\
\cline { 2 - 4 } & Anonim Şirket & 15 & 30,6 \\
\cline { 2 - 4 } & Limited Şirket & 33 & 67,3 \\
\cline { 2 - 4 } & Toplam & 49 & 100 \\
\hline
\end{tabular}

Sayfa/Page | 95

IGU J. Soc. Sci., 4 (2), Spec. Iss. of ICEFM 2017, pp. 89-105.

Tablo 3. Çevre Muhasebesi Ölçeğine Ait Faktör Yüklerinin İncelenmesi

\begin{tabular}{|c|c|}
\hline Maddeler & $\begin{array}{l}\text { Faktör } \\
\text { Yükü }\end{array}$ \\
\hline 1.Çevre muhasebesi işletmeler için önemli bir yönetim aracıdır. & 0,752 \\
\hline 2.Çevre muhasebesi yönetim risklerini azaltmada önemli bir rol oynar. & 0,777 \\
\hline 3.Çevre ile ilgili mali nitelikli işlemlerin muhasebeleştirilmesi gereklidir. & 0,424 \\
\hline 4.Çevre muhasebesinin kullanılması işletme imajına olumlu katkı sağlar & 0,678 \\
\hline 5.Doğal kaynakların kullanımı muhasebeleștirilmelidir. & 0,486 \\
\hline $\begin{array}{l}\text { 6.Çevre muhasebesi sisteminin geliștirilmesi için, yetkili kurum ve } \\
\text { kuruluşlar ile ilgili sektörlerin işbirliği yapması gereklidir. }\end{array}$ & $-0,375$ \\
\hline $\begin{array}{l}\text { 7.Çevresel sorunların önlenmesinde muhasebe bilim dalının da çevreye } \\
\text { iliş̧kin araştırmalar yapması önem arz eder. }\end{array}$ & 0,311 \\
\hline $\begin{array}{l}\text { 8.Çevre muhasebesinin bir sistem olarak algılanması çevre bilincinin } \\
\text { artmasına katkı sağlar. }\end{array}$ & 0,705 \\
\hline $\begin{array}{l}\text { 9.Çevre muhasebesi açısından denetim mekanizmasının ve çevresel } \\
\text { denetçilik faaliyetlerinin geliştirilmesi önem arz eder. }\end{array}$ & 0,523 \\
\hline $\begin{array}{l}\text { 10.Çevre muhasebesi uygulamaları için ayrı bir sistem oluşturularak kendi } \\
\text { kuralları içerisinde işlerlik kazandırılmalıdır. }\end{array}$ & 0,640 \\
\hline KMO & 0,700 \\
\hline Bartlett Test Değeri & $\begin{array}{l}489,027 \\
p=0,000\end{array}$ \\
\hline Açıklanan Varyans (\%) & 34,607 \\
\hline
\end{tabular}


Sayfa/Page | 96

İGÜ Sos. Bil. Derg., 4 (2), ICEFM 2017 Özel Sayısı, ss. $89-105$

Tablo 3'te görüldüğü gibi çevre muhasebesi ölçeği 'ne ait KMO değeri 0,700, Bartlett testi değeri ise anlamlıdır. Bu bulgular ölçek maddelerinin faktör analizi için uygun olduğunu göstermektedir. Yapılan faktör analizinde tüm maddelerin faktör yükleri 0,30'un üzerinde olduğu ve açılklanan varyansın \%34,607 olduğu belirlenmiştir. Çevre muhasebesi ölçeğinde "çevre muhasebesi yönetim risklerini azaltmada önemli rol oynar" maddesi 0,777 'lik oranla en yüksek faktör yüküne sahiptir.

Tablo 4'te görüldüğü gibi Çevre politikaları ölçeği 'ne ait KMO değeri 0,636, Bartlett testi değeri ise anlamlıdır. Bu bulgular ölçek maddelerinin faktör analizi için uygun olduğunu göstermektedir. Yapılan faktör analizinde tüm maddelerin faktör yükleri 0,30'un üzerinde olduğu ve açılanan varyansın \%25,493 olduğu belirlenmiştir. Çevre politikaları ölçeğinde "yatırım kararları alınırken işletmelerin çevresel duyarlılığı da göz önünde bulundurulmalıdır" maddesi 0,696'lık oranla en yüksek faktör yüküne sahiptir

Tablo 4. Çevre Politikaları Ölçeğine Ait Faktör Yüklerinin İncelenmesi

\begin{tabular}{|c|c|}
\hline Maddeler & $\begin{array}{l}\text { Faktör } \\
\text { Yükü }\end{array}$ \\
\hline 1.İ̧sletmemizde çevreye duyarlı bir politika izlenmektedir. & 0,334 \\
\hline $\begin{array}{l}\text { 2.İşletmelerin çevre koruma faaliyetleri ile ilgi olarak Ar -Ge çalışmalarına } \\
\text { düzenli kaynak ayırması gereklidir. }\end{array}$ & 0,330 \\
\hline $\begin{array}{l}\text { 3.Tüketicilerin çevre konusunda duyarlı olması işletmelerin çevre } \\
\text { politikalarını etkiler. }\end{array}$ & 0,656 \\
\hline 4.Çevresel sorunların artması işletmelerin geleceğini de etkilemektedir. & 0,426 \\
\hline $\begin{array}{l}\text { 5.Yatırım kararları alınırken işletmelerin çevresel duyarlılığı da göz } \\
\text { önünde bulundurulmalıdır. }\end{array}$ & 0,696 \\
\hline $\begin{array}{l}\text { 6.İșletmeler üretim süreçlerini ve ürünlerini çevreye zarar vermeyecek } \\
\text { sekilde tasarlamalıdır. }\end{array}$ & 0,669 \\
\hline 7.Çevre dostu ürünlerin üretilmesi işletmelere rekabet avantajı sağlar & 0,507 \\
\hline $\begin{array}{l}\text { 8.Çevresel sorunların önlenmesinde işletmelerin atık yönetimi çalışmaları } \\
\text { yapması önem arz eder. }\end{array}$ & 0,314 \\
\hline 9.Çevresel raporlama yasal düzenlemelerle zorunlu hale getirilmelidir. & 0,419 \\
\hline KMO & 0,636 \\
\hline Bartlett Test Değeri & $\begin{array}{l}206,768, \\
\mathrm{p}=0,000\end{array}$ \\
\hline Açıklanan Varyans (\%) & 25,493 \\
\hline
\end{tabular}


Tablo 5. İl Bazında İşletmelerin Faaliyet Sürelerine Göre Çevre Muhasebesi Ölçeği Puan Ortalamalarının Karşılaştırılması

\begin{tabular}{|l|l|l|l|l|l|}
\hline \multicolumn{2}{|l|}{$\begin{array}{l}\text { İşletmenin Faaliyette } \\
\text { Bulunduğu İl }\end{array}$} & N & Ort. & SS & Önemlilik \\
\hline \multirow{4}{*}{ Erzurum } & $0-5$ Yıl Arası & 24 & 45,17 & 3,33 & \\
\cline { 2 - 6 } & $6-10$ Yll Arası & 17 & 44,29 & 3,22 & $\mathrm{x}{ }^{2} \mathrm{KW}=7,491$ \\
\cline { 2 - 6 } & 10 Yıl ve Üstü & 39 & 42,49 & 3,83 & $\mathbf{0 , 0 2 4}$ \\
\hline \multirow{2}{*}{ Erzincan } & $6-10$ Yıl Arası & 11 & 43,91 & 1,87 & $\mathrm{U}=111,500$ \\
\cline { 2 - 6 } & 10 Yıl ve Üstü & 38 & 42,03 & 2,40 & $\mathrm{p}=\mathbf{0 , 0 1 8}$ \\
\hline
\end{tabular}

Tablo 5'de görüldüğü gibi iller bazında işletmelerin faaliyette bulundukları sürelere göre çevre muhasebesi ölçeği incelendiğinde, Erzurum ve Erzincan'da işletmelerin faaliyet sürelerine göre çevre muhasebesi ölçeği puan ortalaması anlamlı olarak farklıdır $(\mathrm{p}<0,05)$. Erzurum için farkın hangi gruptan kaynaklandığını belirlemek için yapılan ileri analizde (U) 0-5 yıldır faaliyet gösteren işletmelerin anlamlı olarak 10 yıl ve üzeri faaliyet gösterenlerden yüksek puana sahip oldukları belirlenmiştir. Erzincan'da ise, 6-10 yıldır faaliyet gösteren işletmelerin puan ortalaması daha yüksektir $(\mathrm{p}<0,05)$.

Tablo 6. İl Bazında İşletmelerin Faaliyet Gösterdiği Sektörlere Göre Çevre Muhasebesi Ölçeği Puan Ortalamalarının Karşılaştırılması

\begin{tabular}{|c|c|c|c|c|c|}
\hline \multicolumn{2}{|c|}{ İşletmenin Faaliyette Bulunduğu İl } & \multirow{2}{*}{\begin{tabular}{|l}
$\mathbf{N}$ \\
25 \\
\end{tabular}} & \multirow{2}{*}{\begin{tabular}{|l|} 
Ort. \\
43,32 \\
\end{tabular}} & \multirow{2}{*}{\begin{tabular}{|l|} 
SS \\
4,28
\end{tabular}} & \multirow[t]{2}{*}{ Önemlilik } \\
\hline \multirow{7}{*}{ Erzurum } & Gıda Sektörü & & & & \\
\hline & İnşaat Malzemeleri & 10 & 43,90 & 3,51 & \multirow{6}{*}{$\begin{array}{l}x^{2}{ }_{K W}=6,153 \\
p=0,406\end{array}$} \\
\hline & Ağaç/Orman ürünleri & 9 & 42,67 & 4,42 & \\
\hline & Plastik sektörü & 6 & 46,17 & 2,64 & \\
\hline & Cam seramik sektörü & 9 & 45,33 & 3,61 & \\
\hline & Çimento sektörü & 9 & 42,78 & 2,44 & \\
\hline & Diğer Sektörler & 12 & 43,17 & 3,24 & \\
\hline \multirow{4}{*}{ Erzincan } & Gıda Sektörü & 7 & 42,57 & 2,44 & \multirow{4}{*}{$\begin{array}{l}\mathrm{x}^{2}{ }_{\mathrm{KW}}=3,597 \\
\mathrm{p}=0,731\end{array}$} \\
\hline & İnşaat Malzemeleri & 12 & 41,42 & 2,64 & \\
\hline & Ağaç/Orman ürünleri & 6 & 42,50 & 3,15 & \\
\hline & Plastik sektörü & 6 & 43,00 & 1,67 & \\
\hline
\end{tabular}

Sayfa/Page | 97

IGU J. Soc. Sci., 4 (2), Spec. Iss. of ICEFM 2017, pp. 89-105. 
Sayfa/Page | 98

İGÜ Sos. Bil. Derg.,

4 (2), ICEFM 2017 Özel Sayısı, ss. $89-105$

\begin{tabular}{|l|l|l|l|l|}
\hline Cam seramik sektörü & 5 & 43,00 & 1,87 \\
\cline { 2 - 4 } & Çimento sektörü & 2 & 42,50 & 0,71 \\
\cline { 2 - 4 } & Diğer Sektörler & 11 & 42,91 & 2,63 \\
\hline
\end{tabular}

Tablo 6'da görüldüğü gibi iller bazında işletmelerin faaliyette bulunduğu sektörlere göre çevre muhasebesi ölçeği incelendiğinde, Erzurum ve Erzincan illerinde faaliyet gösteren işletmelerin faaliyet gösterdiği sektörlere göre çevre muhasebesi ölçeği puan ortalaması istatistiksel olarak anlamsızdır $(p>0,05)$.

İl bazında işletmelerin çalışan sayılarına göre çevre muhasebesi ölçeği puan ortalamalarının karşılaştırılması Tablo 7'de sunulmuştur.

Tablo 7. İl Bazında İşletmelerin Çalışan Sayılarına Göre Çevre Muhasebesi Ölçeği Puan Ortalamalarının Karşılaştırılması

\begin{tabular}{|c|c|c|c|c|c|}
\hline \multicolumn{2}{|c|}{ İşletmenin Faaliyette Bulunduğu İl } & \multirow{2}{*}{$\begin{array}{l}\mathbf{N} \\
25\end{array}$} & \multirow{2}{*}{\begin{tabular}{|l} 
Ort. \\
42,00
\end{tabular}} & \multirow{2}{*}{\begin{tabular}{|l} 
SS \\
4,56
\end{tabular}} & \multirow[t]{2}{*}{ Önemlilik } \\
\hline \multirow{4}{*}{ Erzurum } & 1-9 Kişi Arası & & & & \\
\hline & 10-49 Kişi Arası & 46 & 44,35 & 3,02 & \multirow{3}{*}{$\begin{array}{l}x^{2} \mathrm{KW}=8,856 \\
p=\mathbf{0 , 0 3 1}\end{array}$} \\
\hline & 50-249 Kişi arası & 8 & 45,50 & 2,78 & \\
\hline & 250 Kişi ve Üzeri & 1 & 40,00 & & \\
\hline \multirow{4}{*}{ Erzincan } & 1-9 Kiși Arası & 11 & 43,73 & 2,20 & \multirow{4}{*}{$\begin{array}{l}x^{2} \text { кw }=4,833 \\
p=0,184\end{array}$} \\
\hline & 10-49 Kişi Arası & 30 & 42,03 & 2,31 & \\
\hline & 50-249 Kişi arası & 6 & 42,50 & 3,15 & \\
\hline & 250 Kişi ve Üzeri & 2 & 41,50 & 0,71 & \\
\hline
\end{tabular}

Tablo 7'de görüldügü iller bazında işletmelerin çalışan sayılarına göre çevre muhasebesi ölçeği incelendiğinde, Erzurum'da çalışan sayılarına göre çevre muhasebesi ölçeği puan ortalaması anlamlı olarak farklıdır $(p<0,05)$. Farkın hangi gruptan kaynaklandığını belirlemek için yapılan ileri analizde (U) 1-9 çalışanı olan işletmelerin anlamlı olarak 10-49 çalışanı olanlardan düşük puan ortalamasına sahip oldukları belirlenmiştir. Erzincan ilinde ise çalışan sayılarına göre çevre muhasebesi ölçeği puan ortalaması istatistiksel olarak anlamsızdır ( $\mathrm{p}>0,05)$.

İl bazında işletmelerin hukuki yapılarına göre çevre muhasebesi ölçeği puan ortalamalarının karşılaştırılması Tablo 8'de sunulmuştur. 
Tablo 8. İl Bazında İşletmelerin Hukuki Yapılarına Göre Çevre Muhasebesi Ölçeği Puan Ortalamalarının Karşılaștırılması

\begin{tabular}{|c|c|c|c|c|c|}
\hline \multicolumn{2}{|c|}{ İşletmenin Faaliyette Bulunduğu İl } & $\mathbf{N}$ & Ort. & SS & Önemlilik \\
\hline \multirow{4}{*}{ Erzurum } & Adi Şirket & 2 & 42,50 & 0,71 & \multirow{4}{*}{$\begin{array}{l}x^{2}{ }_{K W}= \\
1,098 \\
p=0,778\end{array}$} \\
\hline & Kollektif Şirket & 1 & 41,00 & & \\
\hline & Anonim Şirket & 25 & 43,56 & 2,89 & \\
\hline & Limited Şirket & 52 & 43,83 & 4,16 & \\
\hline \multirow{3}{*}{ Erzincan } & Adi Şirket & 1 & 40,00 & . & \multirow{3}{*}{$\begin{array}{l}x^{2}{ }_{\mathrm{KW}}= \\
2,798 \\
\mathrm{p}=0,247\end{array}$} \\
\hline & Anonim Şirket & 15 & 41,87 & 2,42 & \\
\hline & Limited Şirket & 33 & 42,79 & 2,38 & \\
\hline
\end{tabular}

Tablo 8'de görüldüğü gibi iller bazında faaliyet gösteren işletmelerin hukuki yapılarına göre çevre muhasebesi ölçeği incelendiğinde, Erzurum ve Erzincan illerinde faaliyet gösteren işletmelerin hukuki yapılarına göre çevre muhasebesi ölçeği puan ortalaması istatistiksel olarak anlamsızdır ( $p>0,05)$.

Tablo 9. İl Bazında İşletmelerin Çevre Analizi Yapma Durumuna Göre Çevre Muhasebesi Ölçeği Puan Ortalamalarının Karşılaştırılması

\begin{tabular}{|c|c|c|c|c|c|}
\hline \multicolumn{2}{|c|}{$\begin{array}{l}\text { İşletmenin Faaliyette } \\
\text { Bulunduğu İl }\end{array}$} & \multirow{2}{*}{$\begin{array}{l}\mathbf{N} \\
30\end{array}$} & \multirow{2}{*}{\begin{tabular}{|l|} 
Ort. \\
44,43
\end{tabular}} & \multirow{2}{*}{\begin{tabular}{|l} 
SS \\
2,96
\end{tabular}} & \multirow{3}{*}{$\begin{array}{l}\text { Önemlilik } \\
U=631,000 \\
p=0,235\end{array}$} \\
\hline \multirow{2}{*}{ Erzurum } & Evet & & & & \\
\hline & Hayır & 50 & 43,22 & 4,07 & \\
\hline \multirow{2}{*}{ Erzincan } & Evet & 29 & 42,41 & 2,56 & \multirow{2}{*}{$\begin{array}{l}\mathrm{U}=284,500 \\
\mathrm{p}=0,910\end{array}$} \\
\hline & Hayır & 20 & 42,50 & 2,24 & \\
\hline
\end{tabular}

Tablo 9'da görüldüğü gibi iller bazında işletmelerin çevre analizi yapma durumlarına göre çevre muhasebesi ölçeği incelendiğinde, Erzurum ve Erzincan illerinde faaliyet gösteren işletmelerin çevre analizi yapma durumuna göre çevre muhasebesi ölçeği puan ortalaması istatistiksel olarak anlamsizdır $(\mathrm{p}>0,05)$.

Sayfa/Page | 99

IGU J. Soc. Sci., 4 (2), Spec. Iss. of ICEFM 2017, pp. 89-105. 
Sayfa/Page | 100

İGÜ Sos. Bil. Derg.,

4 (2), ICEFM 2017 Özel Sayısı ss. 89-105.
Tablo 10. İl Bazında İşletmelerin Faaliyet Sürelerine Göre Çevre Politikaları Ölçeği Puan Ortalamalarının Karşılaștırılması

\begin{tabular}{|l|l|l|l|l|l|}
\hline \multicolumn{2}{|l|}{ Issletmenin Faaliyette Bulunduğu İl } & N & Ort. & SS & Önemlilik \\
\hline \multirow{3}{*}{ Erzurum } & $0-5$ Yll Arası & 24 & 39,92 & 2,93 & \multirow{2}{*}{${ }^{2} \mathrm{KW}=7,142$} \\
\cline { 2 - 6 } & $6-10$ Yll Arası & 17 & 38,35 & 4,09 & $\mathrm{p}=\mathbf{0 , 0 2 8}$ \\
\cline { 2 - 6 } & 10 Yıl ve Üstü & 39 & 41,13 & 2,49 & \\
\hline \multirow{3}{*}{ Erzincan } & $6-10$ Yll Arası & 11 & 41,45 & 1,75 & $\mathrm{U}=155,500$ \\
\cline { 2 - 6 } & 10 Yll ve Üstü & 38 & 40,74 & 1,83 & $\mathrm{p}=0,183$ \\
\hline
\end{tabular}

Tablo 10'da görüldüğü gibi iller bazında işletmelerin faaliyette oldukları süre ile çevre politikaları ölçeği incelendiğinde, Erzurum'da faaliyet süresine göre çevre politikaları ölçeği puan ortalaması anlamlı olarak farklıdır $(p<0,05)$. Farkın hangi gruptan kaynaklandığını belirlemek için yapılan ileri analizde (U) 6-10 yıldır faaliyet gösteren işletmelerin anlamlı olarak 10 yıl ve üzeri faaliyet gösterenlerden düşük puana sahip oldukları belirlenmiştir. Erzincan ilinde faaliyet gösteren işletmelerin faaliyet süresine göre çevre politikaları ölçeği puan ortalaması istatistiksel olarak anlamsızdır ( $p>0,05)$.

Tablo 11. İl Bazında İşletmelerin Faaliyet Gösterdiği Sektörlere Göre Çevre Politikaları Ölçeği Puan Ortalamalarının Karşılaştırılması

\begin{tabular}{|c|c|c|c|c|c|}
\hline \multicolumn{2}{|c|}{ İşletmenin Faaliyette Bulunduğu İl } & \multirow{2}{*}{$\begin{array}{l}\mathbf{N} \\
25\end{array}$} & \multirow{2}{*}{\begin{tabular}{|l} 
Ort. \\
40,04 \\
\end{tabular}} & \multirow{2}{*}{$\begin{array}{l}\text { SS } \\
2,79 \\
\end{array}$} & \multirow{2}{*}{ Önemlilik } \\
\hline \multirow{7}{*}{ Erzurum } & Gıda Sektörü & & & & \\
\hline & İnşaat Malzemeleri & 10 & 39,50 & 5,06 & \multirow{6}{*}{$\begin{array}{l}x^{2}{ }_{k W}=8,34 \\
9 \\
p=0,214\end{array}$} \\
\hline & Ağaç/Orman ürünleri & 9 & 40,11 & 2,57 & \\
\hline & Plastik sektörü & 6 & 41,83 & 2,40 & \\
\hline & Cam seramik sektörü & 9 & 39,44 & 4,16 & \\
\hline & Çimento sektörü & 9 & 39,22 & 2,05 & \\
\hline & Diğer Sektörler & 12 & 41,50 & 2,50 & \\
\hline \multirow{2}{*}{ Erzincan } & Gıda Sektörü & 7 & 41,43 & 1,27 & \multirow{2}{*}{$\begin{array}{l}x^{2}{ }_{\mathrm{KW}}=8,32 \\
4\end{array}$} \\
\hline & İnşaat Malzemeleri & 12 & 39,92 & 1,78 & \\
\hline
\end{tabular}




\begin{tabular}{|l|l|l|l|l|l|}
\hline Ağaç/Orman ürünleri & 6 & 41,67 & 1,75 & $\mathrm{p}=0,215$ \\
\cline { 1 - 4 } & Plastik sektörü & 6 & 40,50 & 1,22 & \\
\cline { 1 - 4 } Cam seramik sektörü & 5 & 40,20 & 2,95 & \\
\cline { 1 - 3 } & Çimento sektörü & 2 & 41,50 & 2,12 & \\
\cline { 1 - 4 } & Diğer Sektörler & 11 & 41,64 & 1,57 & \\
\hline
\end{tabular}

Tablo 11'de görüldüğü gibi iller bazında işletmelerin faaliyette bulundukları sektörler ile çevre politikaları ölçeği incelendiğinde, Erzurum ve Erzincan illerinde faaliyet gösteren işletmelerin faaliyet gösterilen sektöre göre çevre politikaları ölçeği puan ortalaması istatistiksel olarak anlamsızdır $(p>0,05)$.

Tablo 12. İl Bazında İşletmelerin Çalışan Sayılarına Göre Çevre Politikaları Ölçeği Puan Ortalamalarının Karşılaștırılması

\begin{tabular}{|c|c|c|c|c|c|}
\hline \multicolumn{2}{|c|}{ İşletmenin Faaliyette Bulunduğu İl } & \multirow{2}{*}{\begin{tabular}{|l}
$\mathbf{N}$ \\
25
\end{tabular}} & \multirow{2}{*}{$\begin{array}{l}\text { Ort. } \\
41,00\end{array}$} & \multirow{2}{*}{\begin{tabular}{|l} 
SS \\
2,60
\end{tabular}} & \multirow{3}{*}{$\begin{array}{l}\text { Önemlilik } \\
\mathrm{X}^{2} \mathrm{KW}=1,752\end{array}$} \\
\hline \multirow{4}{*}{ Erzurum } & 1-9 Kişi Arası & & & & \\
\hline & 10-49 Kişi Arası & 46 & 39,78 & 3,31 & \\
\hline & 50-249 Kişi arası & 8 & 39,75 & 4,03 & \multirow[t]{2}{*}{$p=0,625$} \\
\hline & 250 Kişi ve Üzeri & 1 & 41,00 & & \\
\hline \multirow{4}{*}{ Erzincan } & 1-9 Kişi Arası & 11 & 41,64 & 1,43 & \multirow{4}{*}{$\begin{array}{l}\mathrm{x}^{2} \mathrm{KW}=3,248 \\
\mathrm{p}=0,355\end{array}$} \\
\hline & 10-49 Kişi Arası & 30 & 40,73 & 1,98 & \\
\hline & 50-249 Kişi arası & 6 & 40,83 & 1,33 & \\
\hline & 250 Kişi ve Üzeri & 2 & 39,50 & 2,12 & \\
\hline
\end{tabular}

Tablo 12'de görüldüğü gibi iller bazında işletmelerin çalışan sayıları ile çevresel politikalar ölçeği incelendiğinde, Erzurum ve Erzincan illerinde faaliyet gösteren işletmelerin çalışan sayılarına göre çevre politikaları ölçeği puan ortalaması istatistiksel olarak anlamsızdır $(p>0,05)$.

İl bazında işletmelerin hukuki yapılarına göre çevre politikaları ölçeği puan ortalamalarının karşılaştırılması Tablo 13'de sunulmuştur. 
Sayfa/Page | 102

İGÜ Sos. Bil. Derg., 4 (2), ICEFM 2017 Özel Sayısı ss. $89-105$
Tablo 13. İl Bazında İşletmelerin Hukuki Yapılarına Göre Çevre Politikaları Ölçeği Puan Ortalamalarının Karşılaștırılması

\begin{tabular}{|c|c|c|c|c|c|}
\hline \multicolumn{2}{|c|}{ İşletmenin Faaliyette Bulunduğu İl } & $\mathbf{N}$ & Ort. & SS & Önemlilik \\
\hline \multirow{4}{*}{ Erzurum } & Adi Şirket & 2 & 39,00 & 1,41 & \multirow{4}{*}{$\begin{array}{l}x^{2} \text { KW }=2,558 \\
p=0,465\end{array}$} \\
\hline & Kollektif Şirket & 1 & 41,00 & & \\
\hline & Anonim Şirket & 25 & 40,88 & 2,39 & \\
\hline & Limited Şirket & 52 & 39,87 & 3,53 & \\
\hline \multirow{3}{*}{ Erzincan } & Adi Şirket & 1 & 40,00 & . & \multirow{3}{*}{$\begin{array}{l}x^{2} \text { Кw }=1,062 \\
p=0,588\end{array}$} \\
\hline & Anonim Şirket & 15 & 40,67 & 1,99 & \\
\hline & Limited Şirket & 33 & 41,03 & 1,78 & \\
\hline
\end{tabular}

Tablo 13'de görüldüğü gibi iller bazında işletmelerin hukuki yapılarına göre çevre politikaları ölçeği incelendiğinde, Erzurum ve Erzincan illerinde faaliyet gösteren işletmelerin hukuki yapılarına göre çevre politikaları ölçeği puan ortalaması istatistiksel olarak anlamsızdır $(p>0,05)$.

Tablo 14. İl Bazında İşletmelerin Çevre Analizi Yapma Durumuna Göre Çevre Politikaları Ölçeği Puan Ortalamalarının Karşılaştırılması

\begin{tabular}{|c|c|c|c|c|c|}
\hline \multicolumn{2}{|c|}{$\begin{array}{l}\text { İşletmenin Faaliyette } \\
\text { Bulunduğu İl }\end{array}$} & \multirow{2}{*}{\begin{tabular}{|l}
$\mathbf{N}$ \\
30
\end{tabular}} & \multirow{2}{*}{\begin{tabular}{|l} 
Ort. \\
39,97
\end{tabular}} & \multirow{2}{*}{\begin{tabular}{|l} 
SS \\
2,88
\end{tabular}} & \multirow{2}{*}{$\begin{array}{l}\text { Önemlilik } \\
U=668,500\end{array}$} \\
\hline & Evet & & & & \\
\hline ETZurum & Hayır & 50 & 40,30 & 3,36 & $\mathrm{P}=0,413$ \\
\hline \multirow{2}{*}{ Erzincan } & Evet & 29 & 41,03 & 1,92 & $U=266,000$ \\
\hline & Hayır & 20 & 40,70 & 1,69 & $\mathrm{P}=0,612$ \\
\hline
\end{tabular}

Tablo 14'de görüldüğü gibi iller bazında işletmelerin çevre analizi yapma durumlarına göre çevre politikaları ölçeği incelendiğinde, Erzurum ve Erzincan illerinde faaliyet gösteren işletmelerin çevre analizi yapma durumuna göre çevre politikaları ölçeği puan ortalaması istatistiksel olarak anlamsizdır $(\mathrm{p}>0,05)$. 


\section{Sonuç ve Öneriler}

Çevresel sorunların gün geçtikçe artması, doğadaki kıt kaynakların aşırı bir biçimde kullanılması ve benzeri nedenlerden dolayı insanoğlunun çevreye karşı olan duyarlılığı artmıştır. Bu gelişmelere paralel olarak muhasebenin çevre ile ilişkilendirilmesi gerekliliği önem kazanmıștır. Küresel rekabet ortamında gerek hayatta kalabilmek gerekse sınırsız sayıda olan insan ihtiyaçlarını karşılamak amacıyla faaliyet gösteren işletmeler üretim faaliyetleri esnasında birçok çevresel kaynağı kullanmaktadırlar. Dolayısıyla bu bağlamda işletmelerin çevre ile ilgili finansal nitelikli faaliyetlerinin muhasebeleştirilmesi gerekmektedir. Çevresel sorunların ortadan kaldırılabilmesi ve doğal kaynakların aşırı tüketiminin önlenebilmesi amacıyla çevresel konuların muhasebe sistemine dâhil edilmesi önem arz etmektedir. $\mathrm{Bu}$ bağlamda literatürde yeşil muhasebe olarak da adlandırılan çevre muhasebesi çevresel sorunların önlenebilmesinde, işletmelerin çevresel performanslarının değerlendirilmesinde, çevresel sorunları önlemek içi katlanılan maliyetlerin kayıt altına alınmasında önemli tol oynamaktadır. Yapılan araştırma sonuçlarına göre gerek Erzurum gerekse Erzincan'da faaliyet gösteren üretim işletmelerinden kurumsal kimliğe sahip olanların çevre muhasebesi ve çevresel politikalara daha fazla önem verdiği tespit edilmiştir.

Küresel rekabet ortamında firmaların hayatta kalabilmeleri, toplum nezdinde çevreci işletme imajı oluşturabilmeleri ve farklılaşan tüketici taleplerine cevap verebilmeleri amacıyla çevreye yönelik politikalar oluşturmaları ve oluşturulan politikaların etkin bir biçimde uygulanması önem arz etmektedir. Yapılan araştırma sonucunda Erzurum ve Erzincan illerinde faaliyet gösteren kurumsal nitelikteki işletmelerin özellikle 10 yll ve üzeri faaliyette bulunanların çevresel politikalara daha fazla önem verdikleri tespit edilmiştir. Yapılan araştırma sonuçlarına bağlı olarak çeşitli önerilerde bulunabiliriz. Bunlar:

$>$ Çevre muhasebesi uygulamalarında kalitenin artırılabilmesi için denetim mekanizmasının ve çevresel denetim faaliyetlerinin etkin bir biçimde yürütülmesi için gerekli çalışmaların yapılması,

> Çevre ile ilgili parasal olarak ifade edilebilen işlemlerin tarafsız bir biçimde muhasebeleştirilmesi ve çevresel performansın değerlendirilmesinde çevresel raporlamanın yasal zemine oturtulabilmesi için gerekli yasal düzenlemelerin yapılması,

$>$ Toplumda oluşan ve giderek yaygınlaşan çevre bilincinin etkisiyle tüketiciler çevreci ürünleri tercih etmektedir. $\mathrm{Bu}$ doğrultuda işletmelerin gerek rekabet avantajı elde edebilmeleri gerekse kârlılıklarını artırabilmeleri için ürünlerini ve üretim süreçlerinin çevreye zarar vermeyecek bir biçimde tasarlamalı,

Sayfa/Page | 103

IGU J. Soc. Sci., 4 (2), Spec. Iss. of ICEFM 2017, pp. 89-105. 
Sayfa/Page | 104

İGÜ Sos. Bil. Derg., 4 (2), ICEFM 2017 Özel Sayıs ss. $89-105$
> Doğadaki kıt olan kaynakların hoyratça kullanımı işletmelerin uzun vadede üretim faaliyetlerinin aksamasına neden olabilir. Bunun içindir ki doğadaki kıt kaynakların etkin bir biçimde kullanımı sağlanmalı,

$>$ İşletmeler yatırım kararları alırken sadece kendi çıkarlarını düşünerek hareket etmemeli, karşılıklı etkileşim içinde oldukları çevreyi ve çevresel faktörleri de göz önünde bulundurmalı,

İşletmeler çevreci işletme imajı oluşturmada ve bu imajın sürekliliğini sağlamada çevresel politikalara ihtiyaç duymaktadırlar. Bu bağlamda çevresel politikaların oluşturulmasında çevreci kuruluşlarla birlikte hareket edilerek oluşturulan politikaların yürütülmesinde gerekli özen gösterilmelidir.

\section{KAYNAKÇA}

BALTACI, Füsun Özay, "Çevre Maliyetleri ve Bir Sanayi İşletmesinde Uygulama”, Kocaeli Üniversitesi, Kocaeli, 2009 (Yayımlanmamış Yüksek Lisans Tezi).

ÇALIŞ, Yıldırım, “Çevresel Maliyetlerin Muhasebeleştirilmesi”, Marmara Üniversitesi İ.İ.B.Dergisi, Cilt XXXIV, Sayı 1, 2013, ss. 175-190.

ÇELIKK, Muhsin, "Çevreye Duyarlı Muhasebe", Muhasebe Finansman Dergisi, Sayı 33, Ocak, 2007, ss. 151-161.

GRAY, R., Bebbington, J. Walters, D, Accounting for the Environment, Founded by the Chartered Association of Certified Accountants, London: Paul Chapman, 1993, s. 7.

GÜVEMLİ, Oktay ve GÖKDENİZ, Ümit, "Çevre Muhasebesindeki Gelişmeler”, Muhasebe Bilim Dünyası Dergisi, Cilt 1, Sayı 4, 1996, ss. 24-28.

HİÇYORULMAZ, Ela, "Çevre Muhasebesi ve Çimento Fabrikalarının Çevre Muhasebesine Olan Duyarlılığı: Çorum Votorantim Çimento Fabrikası Uygulaması", Hitit Üniversitesi, Çorum. 2015 (Yayımlanmamış Yüksek Lisans Tezi).

KIRLIOĞLU, Hilmi ve CAN, Ahmet Vecdi, Çevre Muhasebesi, Değişim Yayınları, Sakarya, 1998, s. 56.

TU, Jui-Che; HUANG, Hsieh-Shan, "Analysis on the relationship between green accounting and green design for enterprises." Sustainability. Volume 7, Number 5, 2015, ss. 6264-6277. 
TUĞLU, Umut," Çevre Muhasebesi ve Alanya'daki Bir Konaklama İşletmesindeki Uygulanması", Akdeniz Üniversitesi, Antalya, 2010 (Yayımlanmamış Yüksek Lisans Tezi).

\section{Summary}

In other words, environmental accounting, which is expressed as accounting for the resulting effects of the use of natural resources in the environment, is based on the concept of social responsibility at the basis of natural resources accounting. The aim of our work in this direction is to determine the level of importance given to environmental accounting and environmental policy by the production enterprises operating in Erzurum and Erzincan provinces within the framework of social responsibility concept. In this study, the characteristics of the enterprises in the framework of the model created by using the factor analysis method and the environmental accounting practices and the environmental policies were compared. In analyzes that have been made, it was determined that there is a significant relationship between the activity periods of the enterprises and the activities they are engaged in, environmental accounting and environmental policies, in particular, it has been determined that institutional enterprises operating in the Erzurum province attach more importance to environmental policy.

Environmental accounting, also referred to as green accounting in the literature, plays an important role in preventing environmental problems, in assessing the environmental performance of businesses, and in recording costs that are burdensome to prevent environmental problems. According to the research results, it is determined that Erzurum gives more importance to environmental accounting and environmental policy to those who have corporate identity from manufacturing enterprises operating in Erzincan.

It is important for companies to survive in the global competitive environment, to create environmentalist image in society and to create policies towards the environment in order to be able to respond to differentiated consumer demands and to implement policies effectively. As a result of the research, it has been determined that institutional enterprises operating in the Erzurum and Erzincan provinces pay more attention to environmental policy, especially those who operate for 10 years or more.

Sayfa/Page | 105

IGU J. Soc. Sci., 4 (2), Spec. Iss. of ICEFM 2017, pp. 89-105. 